\title{
$-5$ \\ Proteomic research and diagnosis in bladder cancer: state of the art review
}

\author{
Jorge Luis Wilson Jr. ${ }^{1}$, Mariana Pereira Antoniassi ${ }^{1}$, Paula Intasqui Lopes ${ }^{1}$, Hatylas Azevedo ${ }^{1}$ \\ ${ }^{1}$ Departamento de Cirurgia, Divisão de Urologia, Universidade Federal de São Paulo - UNIFESP, São \\ Paulo, SP, Brasil
}

\section{ABSTRACT}

Purpose: Proteomic biomarkers have been emerging as alternative methods to the gold standard procedures of cystoscopy and urine cytology in the diagnosis and surveillance of bladder cancer (BC). This review aims to update the state of the art of proteomics research and diagnosis in $\mathrm{BC}$.

Materials and Methods: We reviewed the current literature related to $\mathrm{BC}$ research on urinary, tissue, blood and cell line proteomics, using the Pubmed database.

Findings: Two urinary protein biomarkers are FDA-approved (NMP22 ${ }^{\circledR}$ and BTA $^{\circledR}$ tests), only if performed along with cystoscopy for surveillance after initial diagnosis, but not in the primary diagnostic setting due to high false-positive rates in case of infections, stones and hematuria. There are a great number of non-FDA approved proteins being studied, with good preliminary results; panels of proteins seem valuable tools to be refined in ongoing trials. Blood proteins are a bigger challenge, because of the complexity of the serum protein profile and the scarcity of blood proteomic studies in BC. Previous studies with the BC tissue proteome do not correlate well with the urinary proteome, likely due to the tumor heterogeneity. Cell line proteomic research helps in the understanding of basic mechanisms that drive $\mathrm{BC}$ development and progression; the main difficulty is culturing low-grade tumors in vitro, which represents the majority of $\mathrm{BC}$ tumors in clinical practice.

Conclusion: Protein biomarkers have promising value in the diagnosis, surveillance and prognostic of BC. Urine is the most appropriate body fluid for biomarker research in $\mathrm{BC}$ due to its easiness of sampling, stability and enrichment of shed and secreted tumor-specific proteins. Panels of biomarkers may exhibit higher sensitivity than single proteins in the diagnosis of $\mathrm{BC}$ at larger populations due to clinical and tumor heterogeneity. Prospective clinical trials are warranted to validate the relevance of proteomic data in the clinical management of BC.

\section{ARTICLE INFO}

Jorge Luis Wilson Jr

http://orcid.org/0000-0002-7475-4660

\section{Keywords:}

Urinary Bladder Neoplasms;

Proteomics; Biomarkers

Int Braz J Urol. 2021; 47: 503-14

Submitted for publication:

April 30, 2020

Accepted after revision:

May 02, 2020

Published as Ahead of Print:

May 10, 2020

\section{INTRODUCTION}

Bladder cancer (BC) represents the 9th most common cancer in the World. In Brazil, 9.480 new cases were estimated in $2018(1,2)$. The most common histology is the transitional cell carcinoma, accounting for about 95\% of cases. The majority of the patients are diagnosed at an early stage and with localized disease, with approximately 70-80\% having non-invasive disease (Ta, $\mathrm{T} 1$, Tis), and the remaining $20-30 \%$ presenting the muscle invasive disease subtype (3). Non-invasive 
tumors have a relapse risk of $31 \%$ to $78 \%$ within 5 years of diagnosis in the low-risk and high-risk subgroups, respectively, whereas progression risk ranges from $0.8 \%$ to $47 \%$, respectively (4).

Despite the advances in new biomarkers, the gold standard for BC diagnosis and follow-up is still based on cystoscopy and urinary cytology (5). Cytology has high specificity (8090\%) but low sensitivity (25-48\%), especially for low-grade tumors (6). Consequently, the definitive diagnosis depends on the identification of the bladder lesion after cystoscopy and biopsy, an invasive and expensive method that usually requires hospitalization (7).

Novel molecular biomarkers have been explored for the noninvasive surveillance of non-muscle invasive bladder cancer (NMIBC), with the potential to minimize the number of control cystoscopies, and to offer a lower-cost approach for cancer monitoring. In the high-risk patient subgroup, the differentiation between NMIBC and muscle-invasive bladder cancer (MIBC) is also of great interest, because it can modify or intensify the surveillance protocol (8). Besides that, new molecular biomarkers may also play an important role as predictors of treatment response (9) with potential better accuracy than clinical or cellular parameters described so far, such as the prognostic value of skeletal muscle index after radical cystectomy (10), or the neutrophil-to-lymphocyte ratio for assessing the response to intravesical treatment with BCG (11). Therefore, this review aimed to update the state of the art of proteomics research in BC, focusing on urinary, cancer tissue, blood and cell lines proteomics studies.

\section{MATERIALS AND METHODS}

We reviewed the current literature that investigated the $\mathrm{BC}$ proteome in urine, tissue, blood and cell lines. Relevant articles were searched in the Pubmed database (http://www.pubmed.gov), using the key words "bladder cancer", "urotelial carcinoma", "urinary proteomics", "tissue proteomics", "blood proteomics" and "cell lines proteomics", in several combinations. Only articles written in English were included.

\section{Urinary proteomics}

Urinary proteins are composed of plasma proteins after they pass through the glomeruli, as well as of those secreted by the urothelium itself. Urinary proteomic studies have identified candidate biomarkers for urogenital diseases, such as acute kidney injury and bladder cancer (12-14). The direct contact with the bladder tumor makes the urinary proteome a prominent clinical source for the search of biomarkers, since it can directly reflect the $\mathrm{BC}$ biology due to the presence of specific proteins that could represent the tumor molecular phenotype at a certain moment $(15,16)$. Moreover, the analysis of urine samples is a non-invasive method that is easier than blood to sample; these atributes have established urine as a good source of urinary biomarkers for BC diagnosis and surveillance. We list below a brief review of the main urine protein biomarkers.

\section{FDA-approved urine protein biomarkers}

The Food and Drug Administration (FDA) has approved the use of five urine-based tests commercially available. Three of them detect DNA, RNA or protein changes in urinary cells (UroVysion ${ }^{\circledR}$ Fluorescent In Situ Hybridization, Cxblad$\operatorname{der}^{\mathrm{TM}}$ and ImmunoCyt ${ }^{\mathrm{TM}}$ ), and the other two quantify proteins released into the urine (NMP22 ${ }^{\circledR}$ and BTA $^{\circledR}$ tests) $(9,17)$. The UroVysion ${ }^{\circledR}$ FISH test detects the aneuploidy of chromosomes 3, 7 and 17, and loss of both 9p21 loci in malignant urothelial cells, showing a diagnostic sensitivity of $87.3 \%$ and specificity of 71.4\% (18). Cxbladder ${ }^{\mathrm{TM}}$ measures the urine mRNA levels of five cancer biomarkers, and combines this information with clinical variables to generate a final binary classification with a sensitivity of $85 \%$ and specificity of $82 \%$ (19). ImmunoCyt ${ }^{\mathrm{TM}}$ is an immunocytochemical test that uses fluorescent-labeled antibodies to detect three proteins commonly found in malignant urothelial cells: glycosylated carcinoembryonic antigen and two less glycosylated mucins. The sensitivity of ImmunoCyt ${ }^{\mathrm{TM}}$ ranges from $38.5 \%$ to $92.1 \%$ across all tumor grades and is generally more sensitive than standard voided cytology. However, the specificity (62\% to $84.2 \%$ ) of ImmunoCyt ${ }^{\mathrm{TM}}$ is inferior to cytology (20). 
The NMP22 ${ }^{\circledR}$ test is available with the comercial name of NMP22 Bladder Chek ${ }^{\circledR}$, (Alere, Waltham, Mass., USA). It detects the nuclear mitotic apparatus protein 1 (NUMA1), also called Nuclear matrix protein-22 (NMP22). This protein is released by apoptotic cells into the urine, and is 25-fold overexpressed in BC cells compared to benign urothelium cells (21). The test is approved for surveillance after initial treatment and for early diagnosis in high-risk cases. Its sensitivity and specificity vary depending on the number of lesions and the tumor grade. Besides the volume of tumor tissue, tumor grade is an additional variable that influences NMP22 levels, with better sensitivity seen for high-grade tumors (22). For the quantitative NMP22 test, sensitivity is around 69\% and specificity around 77\%, while for the qualitative NMP22 test sensitivity is around 58\% and specificity $88 \%(23,24)$. NMP22 has a high rate of false-positive in cases of infections, stones, hematuria or previous instrumentation, with lower specificity compared to urine cytology (25). Although it has a high sensitivity, the high rate of false positive tests represents the most important limitation for its implementation in routine NMIBC management.

The bladder tumor antigen test (BTA ${ }^{\circledR}$ test) identifies a basement membrane antigen related to human complement factor $\mathrm{H}$ that is increased in the urine of $\mathrm{BC}$ patients. It is also available in both qualitative (BTA stat ${ }^{\circledR}$ ) and quantitative (BTA TRAK ${ }^{\circledR}$ ) formats. The BTA stat ${ }^{\circledR}$ test is a single step, qualitative immunochromatographic assay for the detection of bladder tumor associated antigen. This protein protects BC cells from complement-mediated lysis (26). The BTA TRAK ${ }^{\circledR}$ is a quantitative test that is more sensitive than the BTA stat ${ }^{\circledR}(27)$. Both tend to show false positives in the presence of inflammation, hematuria and other genitourinary malignancies, resulting in lower specificity than urine cytology. Their sensitivity and specificity are around 65\% and 75\%, respectively $(23,28)$. The FDA has approved both tests, but only as a companion diagnostic tool with cystoscopy (29).

Despite the approval of these tests by the FDA, they have not yet been incorporated into the American Urological Association or in the Euro- pean Association of Urology clinical guidelines for BC diagnosis and surveillance (30).

\section{NON-FDA Approved urine protein biomarkers}

Novel urinary protein biomarkers have been studied to complement the clinical information provided by the above-mentioned FDA-approved tests. Table- 1 displays a summary from the literature with the most promising novel urinary protein biomarkers. Relative differences in expression of several proteins such as keratins have been observed when comparing normal urothelium to BC. Urothelial cytokeratins are predictors of cell death that can be released into the urine in the presence of cancer. Cytokeratin 8 (KRT8) and 18 (KRT18) are the most studied ones, detected by immunological assays (ELISA), with sensitivity ranging from 50 to $61 \%$ and specificity ranging from 63 to $97 \%$, but with high false-positive rates, being positive in many epithelial cancers, and limited sensibility to low-grade tumors (31-33). The Urinary Bladder Cancer assay (UBC-enzyme-linked immunosorbent assay, IDL Biotech, Borlange, Sweden) is a test that evaluates cytokeratins 8 and 18 in the urine from urothelial tumors, and some studies suggested it performed better than BTA stat test and NMP22 (34). Cytokeratin 20 (KRT20) urinary expression, evaluated by reverse transcription (RT)-polimerase chain reaction (PCR) assay, shows 78 to $87 \%$ sensitivity and 56 to $80 \%$ specificity, but poor sensitivity for low-grade tumors (35).

BLCA-1 and BLCA-4 (bladder cancer markers 1 and 4) are two transcription factors that are found in early stages of BC tissues, even before the appearance of a visible tumor (28), and have no interference with infection, smoking, catheterization or cystitis (36). BLCA-4 is expressed in the normal urothelium of a bladder containing tumor, but not in bladder tissue unaffected by cancer. This was demonstrated in a study where 51 normal tested individuals were negative for BLCA-4 expression, whereas 53 out of 55 samples from patients with BC were positive. Its sensitivity ranges from 89 to $96 \%$ and specificity from 90 to $100 \%$ (37, 38). BLCA-1 is detectable in urine from patients with $\mathrm{BC}$ by immunoassays. It is also detectable in tumor tissue, but not in normal adjacent areas or 
Table 1 - Non-FDA Approved potencial urinary protein biomarkers for bladder cancer detection.

\begin{tabular}{|c|c|c|c|c|}
\hline Proteins & Reference & Subjects & Sensivity & Specificity \\
\hline $\begin{array}{l}\text { Cytokeratin } 8 \text { and } 18 \\
\text { (KRT8 and KRT18) }\end{array}$ & Mian et al. 2000 (34) & 54 histologically UCC, 186 controls & $65 \%$ & $92 \%$ \\
\hline Cytokeratin 20 (KRT20) & Mi et al. 2018 (35) & 2291 BC cases, 1182 controls & $79 \%$ & $90 \%$ \\
\hline $\begin{array}{l}\text { Bladder cancer markers } 1 \\
(B L C A-1)\end{array}$ & Myers-Irvin et al. 2005 (39) & $25 \mathrm{BC}$ patients, 46 controls & $80 \%$ & $87 \%$ \\
\hline $\begin{array}{l}\text { Bladder cancer markers } 4 \\
(B L C A-4)\end{array}$ & Konety et al. 2000 (37) & $54 \mathrm{BC}$ patients, 51 controls & $89-96 \%$ & $90-100 \%$ \\
\hline Aurora A kinase (AURKA) & de Martino et al. 2015 (40) & $\begin{array}{c}122 \text { BC patients, } 66 \text { controls with } \\
\text { hematuria }\end{array}$ & $83.6 \%$ & $65.2 \%$ \\
\hline $\begin{array}{l}\text { Panel of } 22 \text { urinary } \\
\text { proteins }\end{array}$ & Theodorescu et al. 2006 (43) & $\begin{array}{c}31 \text { BC patients, } 11 \text { healthy individuals, } \\
\text { and } 138 \text { patients with non-malignant } \\
\text { genitourinary disease }\end{array}$ & $100 \%$ & $73 \%$ \\
\hline $\begin{array}{l}4 \text { urinary biomarkers } \\
\text { (PGRMC1, COL1A1, } \\
\text { UMOD and COL3A1) }\end{array}$ & Schiffer et al., 2009 (44) & $\begin{array}{c}71 \text { NMIBC and } 56 \text { MIBC patients, } 297 \\
\text { controls }\end{array}$ & $92 \%$ & $68 \%$ \\
\hline 116 urinary proteins & Frantzi et al, 2016 (45) & $341 \mathrm{BC}$ patients and 110 controls & $91 \%$ & $68 \%$ \\
\hline
\end{tabular}

in bladder tissue from healthy donors. It was detected in 20 of 25 urine samples from BC patients, but only in 6 of 46 normal, high risk, prostate or renal cancer samples, and its expression did not correlate with tumor grade. The sensivity and specificity were $80 \%$ and $87 \%$, respectively (39).

Aurora A kinase (AURKA) is a cell-cycle associated kinase that regulates mitosis and is expressed in BC tissue samples. It was already linked to $\mathrm{BC}$ progression and correlates with stage, grade and prognosis. It also has a good performance in discriminating low-grade BC from normal urothelium, by the Aura Tek FDP TestTM in urine, which can detect $\mathrm{BC}$ recurrence, especialy in patients with haematuria. The sensitivity and specificity of AURKA were 83.6 and $65.2 \%$, respectively $(40,41)$.

Some glycoproteins can be found in low and high-grade NMIBC. Sixty-three glycoproteins were exclusively identified in cancer samples compared with healthy controls, such as increased expression of urinary stem-cell marker CD44, which was associated with high-grade MIBC and poor prognosis (42).

The analysis of panels of urinary proteins is also an interesting approach. Previous studies from Theodorescu et al. (2006), Schiffer et al. (2009) and Frantzi et al. (2016) have already demonstrated that this approach may increase the sensitivity of the $\mathrm{BC}$ diagnosis, although the specificity range is still suboptimal (43-45) (Table-1). Chen et al. have found that the combination of decreased levels of epidermal growth factor (EGF), and increased levels of serum amyloid A-4 protein (SAA4) had higher diagnostic capacity in discriminating BC from hernia patients than either marker alone (46). Members of the serum amyloid A (SAA) family of acute-phase proteins are expressed in inflammation, but the knowlodge of alterations of SAA4 levels in cancer is still limited. The cytoplasmic domain of the human proEGF transmembrane region was reported as a novel suppressor of human thyroid carcinoma cell motility and cathepsin L-mediated elastinolytic invasion $(47,48)$.

The iTRAQ (isobaric tag for relative and absolute quantitation) technique was also applied to discover proteins with differential levels between pooled urine samples from controls and BC patients with different grades/stages, and the results revealed 55 proteins elevated in BC patients; Wes- 
tern blot confirmed the levels of apolipoprotein A-I (APOA1), apolipoprotein A-II (APOA2), heparin cofactor 2 (SERPIND1) precursor and peroxiredoxin-2 (PRDX2) were significantly higher in BC samples. Commercial ELISA for APOA1 confirmed its potential value for diagnosis $(94.6 \%$ sensitivity, 92.0\% specificity) and early detection (83.8\% sensitivity and $94.0 \%$ specificity). Later, the same group used Liquid Chromatography Multiple Reaction Monitoring-Mass Spectrometry (LC-MRM/ MS) approach, and found 12 proteins with higher concentrations in the $\mathrm{BC}$ group than in the hernia and urinary tract infection/hematuria groups, generating a six-peptide marker panel (afamin - AFM, adiponectin - ADIPOQ, complement C4 gamma chain, APOA2 precursor, ceruloplasmin $\mathrm{CP}$, and prothrombin - F2). The AUC was 0.814, with a 76.3\% positive predictive value, and a $77.5 \%$ negative predictive value $(49,50)$.

Besides the main goal of developing protein biomarkers for diagnosis of primary tumor and its surveillance, the distinction of NMIBC and MIBC is also of great interest, because it can dramatically change the management of the disease. Survivin is an anti-apoptotic protein correlated with bladder cancer diagnosis, higher tumor grade and stage, that is also a predictor of invasiveness (51-53). Another prospective study used mass spectrometry to identify a panel of proteins able to discriminate MIBC from NMIBC, which were then validated in additional samples from healthy volunteers, and patients with malignant and nonmalignant genitourinary conditions. Four sequenced polypeptides (uromodulin - UMOD, collagen alpha-1(I) chain - COL1A1, collagen alpha-1(III) chain - COL3A1, and membrane-associated progesterone receptor component 1 - PGRMC1) formed a panel predictive of MIBC, with sensitivity of $81 \%$ and specificity of 57\%. A model including tumor grade and panel polypeptide levels improved sensitivity to $92 \%$ and specificity to $68 \%$ (54).

In addition to evaluating proteins diluted in urine, proteins confined to urinary exosomes are also of great interest. Exosomes are small extracellular vesicles (EVs) with a significant role in different steps of cancer development. These EVs are present in nearly all human body fluids, including urine, and particularly enriched in tumor microenvironment, making them a field of big interest and research for BC biomarkers. Alterations in the content of EVs in BC, particularly in genetic material and protein levels were previously observed (55). Looking specifically to proteins, we have some examples. The tumor-associated calcium-signal transducer 2 (TACSTD2), a cell-surface glycoprotein, is elevated in BC exosomes; TACSTD2 concentrations measured by LC-MRM/ MS were 6.5-fold higher in BC urinary EVs than in hernia urinary EVs $(p=0.02, A U C=0.735)$ (56). Furthermore, EVs purified from the urine of high-grade BC contained significantly higher EGF-like repeat and discoidin I-like domain-containing protein 3 (EDIL-3) levels than exosomes from the urine of healthy controls. EDIL-3 is an extracellular matrix glycoprotein released from endothelial cells and mediates endothelial cell attachment and migration; it is also related to $\mathrm{BC}$ progression (57). Alpha-1-antitrypsin (SERPIN1) and Histone H2B type 1-K (HIST1H2BK) were found in high levels in urinary EVs, and when HIST1H2BK is present, it elevates to 3-fold higher the chance of recurrence (58). Increased Periostin (POSTN)-rich EVs demonstrated higher chance of progression and poor prognosis (59).

\section{Tissue proteomics}

Although urinary proteomic studies may provide valuable insights into tumor biology, this information relates only indirectly to the tumor microenvironment, via its secreted proteins. Thus, the analysis of urine proteome does not allow a full description of the molecular alterations underlying BC. In this context, the direct investigation of proteins present in $\mathrm{BC}$ tissues may improve our understanding of the tumor metabolism, growth and invasiveness in a more direct and in-depth manner. Moreover, it may enhance the understanding about the relationship between tumor and urinary BC proteomes. Table-2 summarizes the most promising novel tissue protein biomarkers.

A great number of studies has tried to correlate the urinary proteome with tissue proteome in BC. This is a very difficult task, because BC is highly heterogeneous, and the individual molecular profile has a significant impact on the disease outcome. Some examples of these proteins are 
Table 2 - Potential tissue protein biomarkers in Bladder Cancer.

\begin{tabular}{|c|c|c|c|}
\hline Protein & Subjects & Context & Results \\
\hline $\begin{array}{l}\text { Profilin-1 (PFN1) } \\
\text { Zoidakis et al., } 2012 \text { (60) }\end{array}$ & $\begin{array}{l}35 \text { patients with stage pTa- } \\
\text { pT2 + cancer }\end{array}$ & $\begin{array}{l}\text { Prediction of } \\
\text { invasiveness }\end{array}$ & $\begin{array}{c}\text { Decreased PFN1 expression in invasive (T2) } \\
\text { versus high risk non-invasive (T1G3) tumors, } \\
\text { correlation with poor prognosis and increased } \\
\text { mortality }\end{array}$ \\
\hline $\begin{array}{l}\text { Histone H2B (H2B) and Zinc } \\
\text { finger protein } 335 \text { (NIF-1) } \\
\text { Frantzi et al., } 2013(61)\end{array}$ & $\begin{array}{l}32 \text { patients with stage } \\
\text { pTa-pT2+ }\end{array}$ & $\begin{array}{l}\text { Prediction of } \\
\text { progression }\end{array}$ & $\begin{array}{l}\text { Potential marker for discriminating BC stages, } \\
\text { association with tumor progression }\end{array}$ \\
\hline $\begin{array}{l}\text { Bladder cancer-associated } \\
\text { protein (BLCAP) } \\
\text { Moreira et al., } 2010 \text { (64) }\end{array}$ & $\begin{array}{l}120 \text { bladder specimens: } \\
\text { histologically normal or } \\
\text { various tumor stages }\end{array}$ & $\begin{array}{l}\text { Prediction of } \\
\text { progression, } \\
\text { prognostic value }\end{array}$ & $\begin{array}{l}\text { Loss of BLCAP expression confers a poorer } \\
\text { prognosis for patients }\end{array}$ \\
\hline $\begin{array}{l}\text { Cystatin B (CSTB) } \\
\text { Feldman et al., } 2009 \text { (63) }\end{array}$ & $\begin{array}{l}37 \mathrm{BC} \text { and } 35 \text { normal } \\
\text { urothelial specimens }\end{array}$ & $\begin{array}{l}\text { Prediction of } \\
\text { recurrence and } \\
\text { progression }\end{array}$ & $\begin{array}{l}\text { Increased CSTB expression correlated with } \\
\text { stage and grade, recurrence and progression }\end{array}$ \\
\hline $\begin{array}{l}\text { Maspin } \\
\text { Kramer et al., } 2010 \text { (66) }\end{array}$ & $\begin{array}{l}162 \text { patients with stages } \\
\text { pTa-T1 cancer (NMIBC) }\end{array}$ & $\begin{array}{l}\text { Prediction of } \\
\text { recurrence and } \\
\text { progression }\end{array}$ & $\begin{array}{l}\text { Low Maspin expression correlated to tumor } \\
\text { progression and recurrence }\end{array}$ \\
\hline $\begin{array}{l}\text { Carbonic anhydrase } 9 \text { (CAIX) } \\
\text { Klatte et al., } 2009 \text { (67) }\end{array}$ & $\begin{array}{c}340 \text { patients with } B C \text { of all } \\
\text { stages }\end{array}$ & $\begin{array}{l}\text { Prediction of } \\
\text { recurrence, } \\
\text { progression and } \\
\quad \text { survival }\end{array}$ & $\begin{array}{l}\text { For NMIBC, higher CAIX was associated with } \\
\text { poorer recurrence-free survival. In MIBC } \\
\text { patients who underwent cystectomy, higher } \\
\text { CAIX related to worse overall survival }\end{array}$ \\
\hline $\begin{array}{l}\text { Cyclin D1 (CCND1) } \\
\text { Seiler et al., } 2014 \text { (68) }\end{array}$ & $\begin{array}{l}152 \text { patients who } \\
\text { underwent radical } \\
\text { cystectomy }\end{array}$ & $\begin{array}{l}\text { Response } \\
\text { to adjuvant } \\
\text { chemotherapy } \\
\text { and survival }\end{array}$ & $\begin{array}{l}\text { High CCND1 levels associated with disease- } \\
\text { specific survival in patients treated with } \\
\text { adjuvant chemotherapy }\end{array}$ \\
\hline $\begin{array}{l}\text { TP53, p21, p27kip1 and p107 } \\
\text { Shariat et al., } 2012 \text { (69) }\end{array}$ & $\begin{array}{l}324 \mathrm{BC} \text { patients with } \\
\text { pT1-T2 who received } \\
\text { radical cystectomy }\end{array}$ & $\begin{array}{l}\text { Prediction of } \\
\text { recurrence and } \\
\text { survival }\end{array}$ & $\begin{array}{l}\text { Increased prediction accuracy for disease } \\
\text { recurrence and cancer specific mortality by } \\
15.6 \% \text { and } 14.8 \% \text {, respectively }(p<0.001)\end{array}$ \\
\hline $\begin{array}{l}\text { Cathepsin E, Maspin, PLK1, } \\
\text { survivin Fristrup et al., } 2012 \\
\text { (70) }\end{array}$ & $\begin{array}{l}693 \text { patients with stages } \\
\text { pTa-T1 cancer (NMIBC) }\end{array}$ & $\begin{array}{l}\text { Prediction of } \\
\text { progression }\end{array}$ & $\begin{array}{l}\text { Expression of cathepsin E, maspin, Plk1, } \\
\text { and survivin significantly associated with } \\
\text { progression to stage T2-T4 bladder cancer }\end{array}$ \\
\hline $\begin{array}{l}\text { Androgen receptor, JMJD2A } \\
\text { and LSD1-AR } \\
\text { Kauffman et al., } 2011 \text { (71) }\end{array}$ & $\begin{array}{l}72 \text { patients who } \\
\text { underwent radical } \\
\text { cystectomy }\end{array}$ & $\begin{array}{l}\text { Prediction of } \\
\text { progression and } \\
\text { survival }\end{array}$ & $\begin{array}{l}\text { Significant reduced expression associated with } \\
\text { cancer stage progression, muscle invasion and } \\
\text { lymph node metastasis }\end{array}$ \\
\hline
\end{tabular}

profilin-1 (PFN1), zinc finger protein 335 (NIF-1), histone H2B (H2B), phosphoglycerate mutase 1 (PGAM1), cystatin B (CSTB), and bladder cancer-associated protein (BLCAP).

PFN1 belongs to the family of profilins which are small actin-binding proteins regulating the dynamics of actin polymerization and cell motility. This protein was found to be differentially expressed in the urine of MIBC patients, compared to NMIBC and benign controls, with high interindividual variability. Using a tissue microarray analysis, a marked decrease of PFN1 expression was observed in the epithelial cells of invasive (T2) versus high risk non-invasive (T1G3) tumors, which was strongly correlated with poor prognosis and increased mortality (60). 
H2B (protein associated with DNA damage response) and NIF-1 (protein involved in histone methyltransferase activity and in nuclear receptor-mediated transcription) were analyzed in urine samples by ELISA, and in BC tissue by immunohistochemistry; results support changes in expression of both proteins in tumor progression, denoting a potential marker for discriminating $\mathrm{BC}$ stages (61).

Another study of urinary and tissue correlation found PGAM1, a vital enzyme in glycolytic pathway that catalyzes the conversion of 3-phosphoglycerate to 2-phosphoglycerate, to be important in tumorigenesis, invasion and metastasis of BC. Immunohistochemical data showed increased expression of PGAM1 in BC tissue correlated with severity of histological grade. The downregulation of PGAM1 upregulated its substrate 3-phosphoglycerate, with consequent downregulation of 2-phosphoglycerate, inhibiting aerobic glycolysis and oxidative pentose phosphate pathway (oxPPP), an essential mechanism to cancer cell proliferation. These findings suggest PGAM1 might be a promising therapeutic target (62).

CSTB is an inhibitor of cathepsin proteases. Cathepsin proteases seem to be increased in cancer, and the balance of the protease/inhibitor axis may play an important role. Increased expression of cystatin B in BC tissue correlated with stage and grade, recurrence and progression (63).

BLCAP is an 87-amino acid, evolutionarily conserved protein, with an unknown cellular function. Its expression and cellular localization were studied in benign bladder urothelium and urothelial carcinomas. Interestingly, BC patients were categorized into four groups based on expression levels and subcellular localization of BLCAP; the increased expression of this protein confers a poorer prognosis for patients (64). Tissue-based molecular markers can have prognostic value not only in $\mathrm{BC}$, but also in upper tract urothelial carcinoma (UTUC) (65).

Maspin is a protein of the family of serine protease inhibitors that participates in angiogenesis and metastasis in tumor tissues; in a study with 162 patients with stages pTa-T1 NMIBC, maspin expression predicted progression with a sensitivity of 95\% and a specificity of 70\% ( $p<0.001)$; and recurrence, with a sensitivity of 52\% and specificity of 67\% (p <0.05) (66).

Carbonic anhydrase 9 (CAIX) was investigated in 340 patients with BC of all stages. All normal urothelial tissue samples were negative for CAIX expression, whereas 71\% of BC expressed CAIX. For NMIBC, higher CAIX expression was associated with poorer recurrence-free survival and, for T1 tumors, a 6.5-fold higher risk of progression into MIBC. In patients who underwent cystectomy, higher CAIX expression was associated with worse overall survival (67).

Cyclin D1 (CCND1) is an important promoter of the cell cycle, whose amplification status was evaluated by fluorescence in situ hybridization and immunohistochemistry on tissue microarrays from 152 lymph node-positive urothelial $\mathrm{BC}$ treated by cystectomy and lymphadenectomy. CCND1 amplification status and CyclinD1 expression were independent risk factors in BC metastasis, and high nuclear CyclinD1 expression in lymph node metastases predicted favorable response to chemotherapy (68).

Combinations of markers may also have accurate prediction. Cell cycle related proteins (p53, pRB, p21 and p27) were tested in 324 BC patients with pT1-T2 who received radical cystectomy. The results showed increased prediction accuracy for disease recurrence and cancer specific mortality by $15.6 \%$ and $14.8 \%$, respectively (p $<0.001$ ) (69).

Another study evaluated the protein expression of cathepsin E, maspin, polo-like kinase 1 (Plk1), and survivin in 693 patients with stages pTa-T1 NMIBC; these proteins were found to be significantly associated with progression to stage T2 to T4 cancer (70).

The expression of Androgen receptor (AR), JMJD2A and LSD1 (recently discovered AR coregulator proteins that mediate AR-dependent transcription) were analysed in 72 radical cystectomy specimens by immunohistochemistry. A significant reduction in all three proteins occurred with cancer stage progression, muscle invasion, extravesical extension, and lymph node metastasis (71).

A recent study stratified three groups of NMIBC tumors based on the tissue proteomic pattern, named NMIBC Proteomic subtypes (NPS). 
The first group (NPS1), with predominant pathology of high stage and grade tumors, overexpresses proteins related to immune and inflammatory reactions, cell proliferation and DNA damage response; the second group (NPS2) presented with mixed pathology tumors, and proteins implicated on epithelial to mesenchymal transition; finally, the third group (NPS3) presented predominant pathology of low stage and grade tumors, with luminal and differentiation markers. NPS1 had the closest proteomic profile of MIBC (72).

\section{Blood proteomics}

Whole blood is collected in a minimally invasive manner, and presents a more complex proteomic profile, which may lead to lower sensitivity (73). The analysis of changes in the serum protein profile of $\mathrm{BC}$ patients can reveal the complex interplay between tumor tissue and the surrounding vascular microenvironment. Proteomic studies using blood are scarce in comparison to urine samples (74).

Bansal et al. described five differentially expressed proteins in BC, of which two (Protein S100-A8 - S100A8 and Protein S100-A9 - S100A9) were accurately capable (AUC 0.94) of differentiating BC from healthy controls (75). Schwamborn et al. have studied the proteomic patterns of serum samples from $\mathrm{BC}$ patients compared to controls, achieving $96.4 \%$ of sensitivity and $86.5 \%$ of specificity in diagnosis of BC (76). Lee et al. found that plasma proteins involved in inflammatory responses were upregulated, while proteins of cytoskeleton and cytoskeletal regulation were downregulated (77).

\section{Cell lines proteomics}

Cell lines originated from $\mathrm{BC}$ are essential tools for basic research, since they can offer the access to mutations and tumor biology without the need to directly access $\mathrm{BC}$ tissue $(78,79)$. A recent systematic review described 127 human $B C$ cell lines, out of which 103 have available molecular data, and 69 were profiled by at least one "omic" technology. The most frequently characterized cell lines are HT-1197, T24, and TCCSUP. Only a small number of these human BC cell lines are of low stage (12/127) and low-grade
(8/127) tumors, mainly due to the difficulty of culturing low-grade tumors in vitro, although low-grade tumors represent the vast majority of clinical BC (80).

Proteomic studies using BC cell lines have already shown some interesting findings. Welton et al. examined EVs from HT1376 BC cell line, and identified 353 proteins, with elevated levels of Platelet glycoprotein 4 (CD36), CD44 antigen (CD44), Trophoblast glycoprotein (TPBG), basigin (BSG), and 5'-nucleotidase (NT5E) (81). Beckham et al. showed that EVs secreted from high-grade BC cell lines leaded to angiogenesis and migration of tumor and endothelial cells, mediated by EDIL3 protein (57). The proteomics of T24 BC cell line identified overexpression of cullin-3 (CUL3), a protein involved in ubiquitination, whose silencing leads to decreased cell proliferation and migration. This protein was associated with higher tumor stage, agressiviness and metastasis (82).

The upregulation of hypoxia-related proteins was also seen on three different BC cell lines (T24, 5637 and HT1376), for example, for hypoxia-inducible fator 1-alpha (HIF1A) and its transcriptionally-regulated protein carbonic anhydrase 9 (CA9). Increased levels of lactate biosynthesis were also observed, indicating anaerobic metabolism, associated with enhanced epithelial to mesenchymal transition features. The interesting fact is that these effects were reversed by reoxygenation, mediated by glycoproteins, opening a potential pathway to target treatment studies in future (83).

\section{CONCLUSIONS}

The analysis of molecular profiling data reveals that $\mathrm{BC}$ is highly heterogeneous, but this detailed molecular characterization seems to be a good strategy to establish better diagnostic, follow-up and treatment interventions, towards an increasingly personalized medicine $(8,84)$. Novel biomarkers can also decrease the economic burden associated with invasive procedures, frequently associated with hospitalization and complications. Panels of biomarkers may be an alternative to increase the sensitivity of the tests for $B C$ diagnosis. Although the currently studied protein 
markers have shown promising value in diagnosis, surveillance and prognostic of $\mathrm{BC}$, prospective clinical trials are needed to validate these proteomic data, with a much bigger challenge to translate its potential to the clinical practice.

\section{ABBREVIATIONS}

$\mathrm{BC}=$ bladder cancer

NMIBC $=$ non-muscle invasive bladder cancer

MIBC = muscle invasive bladder cancer

NUMA1 = nuclear mitotic apparatus protein 1

NMP22 = nuclear matrix protein-22

FDA $=$ Food and Drug Administration

KRT8, KRT18, KRT20 = cytokeratin 8, cytokeratin 18 , cytokeratin 20

$\mathrm{RT}=$ reverse transcription

$\mathrm{PCR}=$ polimerase chain reaction

BLCA- 1 and BLCA-4 = bladder cancer markers 1 and 4

AURKA = aurora A kinase

EGF $=$ epidermal growth factor

SAA4 $=$ serum amyloid A-4 protein

AUC $=$ area under the ROC curve

iTRAQ = isobaric tag for relative and absolute quantitation

APOA1, APOA2 = apolipoprotein A-I, apolipoprotein A-II

SERPIND1 = heparin cofactor 2

PRDX2 = peroxiredoxin-2

LC-MRM/MS = liquid Chromatography Multiple

Reaction Monitoring-Mass Spectrometry

EVs = extracellular vesicles

TACSTD2 = tumor-associated calcium-signal transducer 2

EDIL-3 = EGF-like repeat and discoidin I-like domain-containing protein 3

PFN1 = profilin-1

NIF-1 = zinc finger protein 335

$\mathrm{H} 2 \mathrm{~B}=$ histone $\mathrm{H} 2 \mathrm{~B}$

PGAM1 = phosphoglycerate mutase 1

CSTB $=$ cystatin $\mathrm{B}$

BLCAP = bladder cancer-associated protein

NPS = NMIBC ProteomicSubtypes

\section{CONFLICT OF INTEREST}

None declared.

\section{REFERENCES}

1. Siegel RL, Miller KD, Jemal A. Cancer statistics, 2019. CA Cancer J Clin. 2019;69:7-34.

2. Instituto Nacional do Câncer José Alencar Gomes da Silva. Estimativa para 0 ano de 2020 de taxas brutas e ajustadas de incidência por 100 mil habitantes e do número de casos novos de Câncer, segundo e localização primária. Available at. <https://www.inca.gov.br/sites/ufu.sti.inca.local/files/ media/document/estimativa-2020-incidencia-de-cancer-nobrasil.pdf>

3. Nielsen ME, Smith AB, Meyer AM, Kuo TM, Tyree S, Kim WY, et al. Trends in stage-specific incidence rates for urothelial carcinoma of the bladder in the United States: 1988 to 2006. Cancer. 2014;120:86-95.

4. Sylvester RJ. Natural history, recurrence, and progression in superficial bladder cancer. ScientificWorldJournal. 2006;6:2617-25.

5. Badalament RA, Hermansen DK, Kimmel M, Gay $H$, Herr HW, Fair WR, et al. The sensitivity of bladder wash flow cytometry, bladder wash cytology, and voided cytology in the detection of bladder carcinoma. Cancer. 1987:60:1423-7.

6. Herr HW. Tumor progression and survival of patients with high grade, noninvasive papillary (TaG3) bladder tumors: 15-year outcome. J Urol. 2000;163:60-1; discussion 61-2.

7. Kamat AM, Karam JA, Grossman HB, Kader AK, Munsell M, Dinney CP. Prospective trial to identify optimal bladder cancer surveillance protocol: reducing costs while maximizing sensitivity. BJU Int. 2011;108:1119-23.

8. Frantzi M, Latosinska A, Flühe L, Hupe MC, Critselis $E$, Kramer MW, et al. Developing proteomic biomarkers for bladder cancer: towards clinical application. Nat Rev Urol. 2015;12:317-30.

9. Tomasini JM, Konety BR. Urinary markers/cytology: what and when should a urologist use. Urol Clin North Am. 2013;40:165-73.

10. Ha YS, Kim SW, Kwon TG, Chung SK, Yoo ES. Decrease in skeletal muscle index 1 year after radical cystectomy as a prognostic indicator in patients with urothelial bladder cancer. Int Braz J Urol. 2019;45:686-94.

11. Racioppi M, Di Gianfrancesco L, Ragonese M, Palermo G, Sacco E, Bassi PF. Can Neutrophil-to-Lymphocyte ratio predict the response to $B C G$ in high-risk non muscle invasive bladder cancer? Int Braz J Urol. 2019;45:315-24.

12. Thomas S, Hao L, Ricke WA, Li L. Biomarker discovery in mass spectrometry-based urinary proteomics. Proteomics Clin Appl. 2016;10:358-70. 
13. Ho J, Lucy M, Krokhin 0, Hayglass K, Pascoe E, Darroch G, et al. Mass spectrometry-based proteomic analysis of urine in acute kidney injury following cardiopulmonary bypass: a nested case-control study. Am J Kidney Dis. 2009;53:58495.

14. Orenes-Piñero E, Cortón M, González-Peramato P, Algaba F, Casal I, Serrano A, et al. Searching urinary tumor markers for bladder cancer using a two-dimensional differential gel electrophoresis (2D-DIGE) approach. J Proteome Res. 2007:6:4440-8.

15. Dal Moro F, Valotto C, Guttilla A, Zattoni F. Urinary markers in the everyday diagnosis of bladder cancer. Urologia. 2013;80:265-75.

16. Anderson NL, Anderson NG. Proteome and proteomics: new technologies, new concepts, and new words. Electrophoresis. 1998;19:1853-61.

17. O'Sullivan P, Sharples K, Dalphin M, Davidson P, Gilling P, Cambridge $L$, et al. A multigene urine test for the detection and stratification of bladder cancer in patients presenting with hematuria. J Urol. 2012;188:741-7.

18. Dodurga Y, Avcı CB, Yılmaz S, Nazlı O, Co ulu 0, Cankaya T, et al. UroVysion fluorescence in situ hybridization (UroVysion FISH) assay for detection of bladder cancer in voided urine of Turkish patients: a preliminary study. Contemp Oncol (Pozn). 2013;17:156-60.

19. Kavalieris L, O'Sullivan P, Frampton C, Guilford P, Darling D, Jacobson E, et al. Performance Characteristics of a Multigene Urine Biomarker Test for Monitoring for Recurrent Urothelial Carcinoma in a Multicenter Study. J Urol. 2017;197:141926.

20. Greene KL, Berry A, Konety BR. Diagnostic Utility of the ImmunoCyt/uCyt+ Test in Bladder Cancer. Rev Urol. 2006;8:190-7.

21. Carpinito GA, Stadler WM, Briggman JV, Chodak GW, Church PA, Lamm DL, et al. Urinary nuclear matrix protein as a marker for transitional cell carcinoma of the urinary tract. J Urol. 1996;156:1280-5.

22. Todenhöfer T, Hennenlotter J, Aufderklamm S, Kühs U, Gakis G, Germann M, et al. Individual risk assessment in bladder cancer patients based on a multi-marker panel. J Cancer Res Clin Oncol. 2013;139:49-56.

23. Chou R, Gore JL, Buckley D, Fu R, Gustafson K, Griffin JC, et al. Urinary Biomarkers for Diagnosis of Bladder Cancer: A Systematic Review and Meta-analysis. Ann Intern Med. 2015;163:922-31.

24. Grossman HB, Messing E, Soloway M, Tomera K, Katz G, Berger $Y$, et al. Detection of bladder cancer using a point-ofcare proteomic assay. JAMA. 2005;293:810-6.
25. Sharma S, Zippe CD, Pandrangi L, Nelson D, Agarwal A. Exclusion criteria enhance the specificity and positive predictive value of NMP22 and BTA stat. J Urol. 1999;162:537.

26. Kinders R, Jones T, Root R, Bruce C, Murchison H, Corey M, et al. Complement factor $\mathrm{H}$ or a related protein is a marker for transitional cell cancer of the bladder. Clin Cancer Res. 1998;4:2511-20.

27. Irani J, Desgrandchamps F, Millet C, Toubert ME, Bon D, Aubert J, et al. BTA stat and BTA TRAK: A comparative evaluation of urine testing for the diagnosis of transitiona cell carcinoma of the bladder. Eur Urol. 1999;35:89-92.

28. Konety BR. Molecular markers in bladder cancer: a critical appraisal. Urol Oncol. 2006;24:326-37.

29. Lotan Y, Svatek RS, Malats N. Screening for bladder cancer: a perspective. World J Urol. 2008;26:13-8.

30. Chou R, Buckley D, Fu R, Gore JL, Gustafson K, Griffin J, et al. Emerging Approaches to Diagnosis and Treatment of Non-Muscle-Invasive Bladder Cancer [Internet]. Rockville (MD): Agency for Healthcare Research and Quality (US); 2015. Report No.: 15(16)-EHC017-EF. Available at. <https:// www.ncbi.nlm.nih.gov/books/NBK330472/>

31. Sánchez-Carbayo M, Herrero E, Megias J, Mira A, Espasa $A$, Chinchilla $V$, et al. Initial evaluation of the diagnostic performance of the new urinary bladder cancer antigen test as a tumor marker for transitional cell carcinoma of the bladder. J Urol. 1999;161:1110-5.

32. Ritter R, Hennenlotter J, Kühs U, Hofmann U, Aufderklamm $S$, Blutbacher $P$, et al. Evaluation of a new quantitative pointof-care test platform for urine-based detection of bladder cancer. Urol Oncol. 2014;32:337-44.

33. Alvarez A, Lokeshwar VB. Bladder cancer biomarkers: current developments and future implementation. Curr Opin Urol. 2007;17:341-6.

34. Mian C, Lodde M, Haitel A, Vigl EE, Marberger M, Pycha A. Comparison of the monoclonal UBC-ELISA test and the NMP22 ELISA test for the detection of urothelial cell carcinoma of the bladder. Urology. 2000;55:223-6.

35. Mi Y, Zhao Y, Shi F, Zhang M, Wang C, Liu X. Diagnostic accuracy of urine cytokeratin 20 for bladder cancer: A metaanalysis. Asia Pac J Clin Oncol. 2019;15:e11-e19.

36. Deininger S, Hennenlotter J, Rausch S, Docktor K, Neumann $E$, da Costa IA, et al. No influence of smoking status on the performance of urine markers for the detection of bladder cancer. J Cancer Res Clin Oncol. 2018;144:1367-73.

37. Konety BR, Nguyen TS, Dhir R, Day RS, Becich MJ, Stadler WM, et al. Detection of bladder cancer using a novel nuclear matrix protein, BLCA-4. Clin Cancer Res. 2000;6:2618-25. 
38. Cai $Q$, Wu Y, Guo Z, Gong R, Tang Y, Yang K, et al. Urine BLCA-4 exerts potential role in detecting patients with bladder cancers: a pooled analysis of individual studies. Oncotarget. 2015;6:37500-10.

39. Myers-Irvin JM, Landsittel D, Getzenberg RH. Use of the novel marker BLCA-1 for the detection of bladder cancer. J Urol. 2005; 174:64-8.

40. de Martino M, Shariat SF, Hofbauer SL, Lucca I, Taus C, Wiener $\mathrm{HG}$, et al. Aurora A Kinase as a diagnostic urinary marker for urothelial bladder cancer. World J Urol. 2015;33:105-10.

41. Siemens DR, Morales A, Johnston B, Emerson L. A comparative analysis of rapid urine tests for the diagnosis of upper urinary tract malignancy. Can J Urol. 2003;10:1754-8.

42. Azevedo R, Soares J, Gaiteiro C, Peixoto A, Lima L, Ferreira $D$, et al. Glycan affinity magnetic nanoplatforms for urinary glycobiomarkers discovery in bladder cancer. Talanta. 2018;184:347-55.

43. Theodorescu D, Wittke S, Ross MM, Walden M, Conaway M, Just I, et al. Discovery and validation of new protein biomarkers for urothelial cancer: a prospective analysis. Lancet Oncol. 2006:7:230-40.

44. Schiffer E, Vlahou A, Petrolekas A, Stravodimos K, Tauber R, Geschwend JE, et al. Prediction of muscle-invasive bladder cancer using urinary proteomics. Clin Cancer Res. 2009;15:4935-43.

45. Frantzi M, van Kessel KE, Zwarthoff EC, Marquez M, Rava M, Malats N, et al. Development and Validation of Urine-based Peptide Biomarker Panels for Detecting Bladder Cancer in a Multi-center Study. Clin Cancer Res. 2016;22:4077-86.

46. Chen CL, Lin TS, Tsai CH, Wu CC, Chung T, Chien KY, et al. Identification of potential bladder cancer markers in urine by abundant-protein depletion coupled with quantitative proteomics. J Proteomics. 2013;85:28-43.

47. Yamada T, Miyake N, Itoh K, Igari J. Further characterization of serum amyloid A4 as a minor acute phase reactant and a possible nutritional marker. Clin Chem Lab Med. 2001;39:7-10.

48. Glogowska A, Pyka J, Kehlen A, Los M, Perumal P, Weber E, et al. The cytoplasmic domain of proEGF negatively regulates motility and elastinolytic activity in thyroid carcinoma cells. Neoplasia. 2008;10:1120-30.

49. Chen YT, Chen CL, Chen HW, Chung T, Wu CC, Chen CD, et al. Discovery of novel bladder cancer biomarkers by comparative urine proteomics using iTRAQ technology. J Proteome Res. 2010:9:5803-15.

50. Chen YT, Chen HW, Domanski D, Smith DS, Liang KH, Wu CC, et al. Multiplexed quantification of 63 proteins in human urine by multiple reaction monitoring-based mass spectrometry for discovery of potential bladder cancer biomarkers. J Proteomics. 2012;75:3529-45.
51. Margulis V, Lotan Y, Shariat SF. Survivin: a promising biomarker for detection and prognosis of bladder cancer. World J Urol. 2008;26:59-65.

52. Smith SD, Wheeler MA, Plescia J, Colberg JW, Weiss RM, Altieri DC. Urine detection of survivin and diagnosis of bladder cancer. JAMA. 2001;285:324-8.

53. Horstmann $M$, Bontrup $H$, Hennenlotter J, Taeger D, Weber A, Pesch B, et al. Clinical experience with survivin as a biomarker for urothelial bladder cancer. World J Urol. 2010;28:399-404.

54. Schiffer E, Vlahou A, Petrolekas A, Stravodimos K, Tauber $\mathrm{R}$, Geschwend JE, et al. Prediction of muscle-invasive bladder cancer using urinary proteomics. Clin Cancer Res. 2009;15:4935-43.

55. Yu S, Cao H, Shen B, Feng J. Tumor-derived exosomes in cancer progression and treatment failure. Oncotarget. 2015;6:37151-68.

56. Chen CL, Lai YF, Tang P, Chien KY, Yu JS, Tsai CH, et al. Comparative and targeted proteomic analyses of urinary microparticles from bladder cancer and hernia patients. $J$ Proteome Res. 2012;11:5611-29.

57. Beckham CJ, Olsen J, Yin PN, Wu CH, Ting HJ, Hagen FK, et al. Bladder cancer exosomes contain EDIL-3/Del1 and facilitate cancer progression. J Urol. 2014;192:583-92.

58. Lin SY, Chang $\mathrm{CH}$, Wu HC, Lin CC, Chang KP, Yang CR, et al. Proteome Profiling of Urinary Exosomes Identifies Alpha 1-Antitrypsin and H2B1K as Diagnostic and Prognostic Biomarkers for Urothelial Carcinoma. Sci Rep. 2016;6:34446.

59. Silvers CR, Liu YR, Wu CH, Miyamoto H, Messing EM, Lee YF. Identification of extracellular vesicle-borne periostin as a feature of muscle-invasive bladder cancer. Oncotarget. 2016;7:23335-45.

60. Zoidakis J, Makridakis M, Zerefos PG, Bitsika V, Esteban S, Frantzi M, et al. Profilin 1 is a potential biomarker for bladder cancer aggressiveness. Mol Cell Proteomics. 2012;11:M111.

61. Frantzi M, Zoidakis J, Papadopoulos T, Zürbig $P$, Katafigiotis I, Stravodimos K, et al. IMAC fractionation in combination with LC-MS reveals H2B and NIF-1 peptides as potential bladder cancer biomarkers. J Proteome Res. 2013;12:3969-79.

62. Peng XC, Gong FM, Chen Y, Qiu M, Cheng K, Tang J, et al. Proteomics identification of PGAM1 as a potential therapeutic target for urothelial bladder cancer. J Proteomics. 2016;132:85-92.

63. Feldman AS, Banyard J, Wu CL, McDougal WS, Zetter BR. Cystatin $B$ as a tissue and urinary biomarker of bladder cancer recurrence and disease progression. Clin Cancer Res. 2009;15:1024-31. 
64. Moreira JM, Ohlsson G, Gromov P, Simon R, Sauter G, Celis JE, et al. Bladder cancer-associated protein, a potential prognostic biomarker in human bladder cancer. Mol Cell Proteomics. 2010;9:161-77.

65. Favaretto RL, Zequi SC, Oliveira RAR, Santana T, Costa WH, Cunha IW, et al. Tissue-based molecular markers in upper tract urothelial carcinoma and their prognostic implications. Int Braz J Urol. 2018;44:22-37.

66. Kramer MW, Waalkes S, Hennenlotter J, Serth J, Stenzl A, Kuczyk MA, et al. Maspin protein expression correlates with tumor progression in non-muscle invasive bladder cancer. Oncol Lett. 2010;1:621-6.

67. Klatte T, Seligson DB, Rao JY, Yu H, de Martino M, Kawaoka $\mathrm{K}$, et al. Carbonic anhydrase IX in bladder cancer: a diagnostic, prognostic, and therapeutic molecular marker. Cancer. 2009;115:1448-58.

68. Seiler R, Thalmann GN, Rotzer D, Perren A, Fleischmann A. CCND1/CyclinD1 status in metastasizing bladder cancer: a prognosticator and predictor of chemotherapeutic response. Mod Pathol. 2014;27:87-95.

69. Shariat SF, Chromecki TF, Cha EK, Karakiewicz PI, Sun M, Fradet $Y$, et al. Risk stratification of organ confined bladder cancer after radical cystectomy using cell cycle related biomarkers. J Urol. 2012;187:457-62.

70. Fristrup N, Ulhøi BP, Birkenkamp-Demtröder K, Mansilla F, Sanchez-Carbayo M, Segersten U, et al. Cathepsin E, maspin, Plk1, and survivin are promising prognostic protein markers for progression in non-muscle invasive bladder cancer. Am J Pathol. 2012;180:1824-34.

71. Kauffman EC, Robinson BD, Downes MJ, Powell LG, Lee MM, Scherr DS, et al. Role of androgen receptor and associated lysine-demethylase coregulators, LSD1 and JMJD2A, in localized and advanced human bladder cancer. Mol Carcinog. 2011;50:931-44.

72. Stroggilos R, Mokou M, Latosinska A, Makridakis M, Lygirou V, Mavrogeorgis E, et al. Proteome-based classification of Nonmuscle Invasive Bladder Cancer. Int J Cancer. 2020;146:281-94.

73. Nandagopal L, Sonpavde G. Circulating Biomarkers in Bladder Cancer. Bladder Cancer. 2016;2:369-79.

74. Schwamborn K, Gaisa NT, Henkel C. Tissue and serum proteomic profiling for diagnostic and prognostic bladder cancer biomarkers. Expert Rev Proteomics. 2010;7:897-906.

75. Bansal N, Gupta A, Sankhwar SN, Mahdi AA. Low- and highgrade bladder cancer appraisal via serum-based proteomics approach. Clin Chim Acta. 2014;436:97-103.
76. Schwamborn K, Krieg RC, Grosse J, Reulen N, Weiskirchen $\mathrm{R}$, Knuechel $\mathrm{R}$, et al. Serum proteomic profiling in patients with bladder cancer. Eur Urol. 2009;56:989-96.

77. Lee YR, Chen YW, Tsai MC, Chou HC, Chan HL. Redoxand expression-proteomic analysis of plasma biomarkers in bladder transitional cell carcinoma. Mol Biosyst. 2012;8:3314-24.

78. Bernardo C, Costa C, Palmeira C, Pinto-Leite R, Oliveira $P$, Freitas $R$, et al. What we have learned from urinary bladder cancer models. J Cancer Metastasis Treat. 2016; 2:51-8.

79. Goodspeed A, Heiser LM, Gray JW, Costello JC. TumorDerived Cell Lines as Molecular Models of Cancer Pharmacogenomics. Mol Cancer Res. 2016;14:3-13.

80. Zuiverloon TCM, de Jong FC, Costello JC, Theodorescu D. Systematic Review: Characteristics and Preclinical Uses of Bladder Cancer Cell Lines. Bladder Cancer. 2018;4:16983.

81. Welton JL, Khanna S, Giles PJ, Brennan P, Brewis IA, Staffurth J, et al. Proteomics analysis of bladder cancer exosomes. Mol Cell Proteomics. 2010;9:1324-38.

82. Grau L, Luque-Garcia JL, González-Peramato $P$, Theodorescu D, Palou J, Fernandez-Gomez JM, et al. A quantitative proteomic analysis uncovers the relevance of CUL3 in bladder cancer aggressiveness. PLOS One. 2013;8:e53328.

83. Peixoto A, Fernandes E, Gaiteiro C, Lima L, Azevedo R, Soares J, et al. Hypoxia enhances the malignant nature of bladder cancer cells and concomitantly antagonizes protein 0-glycosylation extension. Oncotarget. 2016;7:63138-63157

84. Ma G, Yang X, Liang Y, Wang L, Li D, Chen Y, et al. Precision medicine and bladder cancer heterogeneity. Bull Cancer. 2018;105:925-31.

Correspondence address: Jorge Luis Wilson Junior, MD Disciplina de Urologia, Universidade Federal de São Paulo - UNIFESP Rua Napoleão de Barros, 715, $2^{\circ}$ andar, Vila Clementino, São Paulo, SP, 04024-002, Brasil Fax: + 5511 5576-4086 E-mail: jorgewilsonjr@gmail.com 